POLIIICAL ECONOMY RESEARCH INSIITUTE

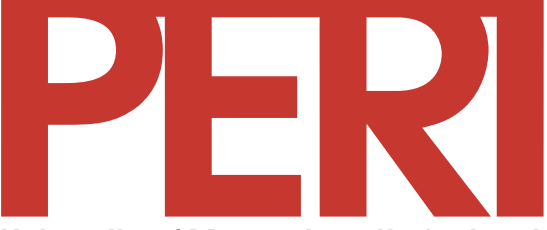

University of Massachusetts Amherst

\title{
The Economic Impact of Living Wage Ordinances
}

\author{
Mark D. Brenner
}

2004

10th floor Thompson Hall University of Massachusetts Amherst, MA, 01003-7510 Telephone: (413) 545-6355 Facsimile: (413) 545-2921

Email:peri@econs.umass.edu Website:

http://www.umass.edu/peri/

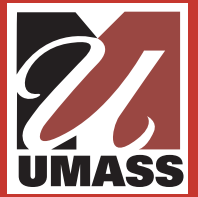




\title{
The Economic Impact of Living Wage Ordinances
}

July, 2003

\author{
Mark D. Brenner \\ Assistant Research Professor \\ Political Economy Research Institute \\ $10^{\text {th }}$ floor Thompson Hall \\ University of Massachusetts \\ Amherst, MA 01003-7510 \\ 413-545-6355 phone \\ 413-577-0261 fax \\ brenner@econs.umass.edu \\ http://www.umass.edu/peri
}

Abstract: Drawing upon both prospective and retrospective evidence, this paper reviews the economic effects of local living wage ordinances. I concentrate my attention on the higher costs these measures create for covered firms, as well as their budgetary implications vis-à-vis cities that adopt them. I also briefly review the effect that living wage laws have had on bidding environment for city service contracts. Based on a range of cost estimates associated with living wage laws, I then examine the adjustment channels firms are likely to pursue when adjusting to higher labor costs, including: raising prices; increasing firm productivity; redistributing income within the firm; laying off employees; and relocating out of the area covered by the living wage mandate.

This review draws from research that I and my colleagues at the Political Economy Research Institute have conducted over the past several years. I am grateful to Robert Pollin and Jeannette Wicks-Lim for their thought-provoking and fruitful collaborations. I am especially indebted to Stephanie Luce for her on-going collaboration, and her careful comments on an early draft of this paper. 


\section{Introduction}

Over the last decade, the United States has witnessed the rapid expansion of a municipal policy initiative known as the living wage ordinance. The aim of these laws is to set a wage floor high enough so that a full-time worker can support a family of three or four at a living standard above the official poverty line (Luce 2002). Most living wage laws apply to large-scale city service contractors, and a limited number apply to firms receiving financial assistance such as tax abatements or other subsidies. In recent years these laws have also been extended to cover private sector businesses with no direct financial ties to the city, and living wage initiatives have emerged in variety of other arenas such as college campuses.

These measures are an effort to improve the stagnating living standards of low-wage workers in the U.S., and to stem the more general trend of rising wage and income inequality witnessed over the past generation. Integrally linked to both phenomena has been the steady erosion of the national minimum wage, which has declined 38 percent from its 1968 peak of \$8.27 (in constant 2002 dollars). To gain a sense of the magnitude of this decline, consider the fact that at its highpoint, an individual working full-time, full-year for the minimum wage had earnings 20 percent above the poverty line for a family of three. By 2002, a similarly situated worker earning the current minimum wage of $\$ 5.15$ fell 25 percent below the three-person poverty line, itself considered by a broad range of experts to be between 25 and 50 percent too low (see the discussion in Chapter 2 of Citro and Michael 1995).

By the end of 2002 more than 100 cities, counties, school boards or other local government bodies across the country had enacted living wage laws. Table 1 profiles the different types of coverage legislated by these measures. From these data we see that more than three quarters (77 percent) of existing living wage ordinances have placed wage standards on 
service contractors, while a much smaller fraction establish standards for economic development assistance (38 percent) or city employment (22 percent). While not immediately apparent from this table, the modern living wage movement has penetrated deep into the fabric of local economic policy-making in the United States. One measure of this success is the fact that by January 2003 cities with living wage ordinances comprised approximately one fifth of the population residing in municipalities of 10,000 people or more, and close to 40 percent of the population in cities larger than $100,000 .^{1}$

\section{[TABLE 1 NEAR HERE]}

But these statistics beg the question, what economic impact have existing living wage measures had? Opponents consistently warn that these initiatives will not help, but will actually harm, low-wage workers and their families. They argue that living wage laws will set off a series of "unintended consequences" which, because of the way wage floors are theorized to operate in market settings, will actually lower the welfare of their intended beneficiaries. Two sets of effects are of particular concern. The first involves the firms covered by living wage requirements, where it is feared that higher wage floors will induce employers to scale back their usage of low-wage labor through means such as workplace reorganization, substitution of new machinery or equipment, or replacement with higher skilled (and already higher paid) workers. In the extreme, the response could even entail relocating out of the area in an effort to avoid the living wage mandate. The second set of effects concerns the cities that pass living wage ordinances. Any of the aforementioned adjustment methods would impose new costs on covered firms, and at least in the case of city service contractors much of this could be passed back to cities in the form of higher contract costs. Such costs to local government could be significant, and they carry with them the risk of reducing the level of existing city services, or creating the 
need for additional taxes. These are matters of serious concern, given the precarious economic position of the lowest-paid segment of the U.S. workforce, the fragile condition of local government finances in the current recession, and the rapid proliferation of living wage measures throughout the country.

This paper will address these basic issues, providing an overview of the available evidence as to the economic effects of living wage ordinances on the local governments that pass such measures and the firms they cover. Because of their recent emergence and rapid proliferation, there is far less research available on the economic impact of living wage laws when compared to state and federal minimum wages. We are fortunate, however, that this body of research has already produced some important insights into the dynamics of local wage mandates, and that it is expanding at a considerable pace.

Before turning to this empirical evidence, it is first useful to examine some of the theoretical and methodological issues involved in studying the economic effects of living wage ordinances. In the next section I review the recent literature on the effects of state and federal minimum wage mandates, drawing out the important differences between living wage ordinances and these other, more universal, wage floors. One such difference, which stems from the targeted nature of living wage laws, is the feasibility of employing publicly available data together with conventional statistical techniques to examine the economic effects of living wage laws. This is an issue of considerable importance, given the recent work of David Neumark and Scott Adams (forthcoming (a) and (b)). As we shall see, precisely because of the important differences between living wages and minimum wages, the approach adopted by Neumark and Adams is methodologically inappropriate for detecting the effects of living wage laws, and non-robust even on its own terms. Ultimately their work offers us only one strong conclusion, namely that 
the most fruitful avenue for evaluating the economic impact of living wage ordinances is at the local level, using various primary data collection methods.

Fortunately virtually all other existing research has followed this more localized approach to examining living wage ordinances, and I review these findings in sections three and four. I start in section three by summarizing the results of a series of economic impact studies conducted prior to the passage of living wage ordinances in several large municipalities. I refer to these findings as prospective (or ex ante) evidence. This sort of analysis is a mainstay of public policy-making in a variety of arenas from environmental regulation to tax reform, and is particularly useful when there is no sufficiently comparable historical experience to draw upon while crafting legislation. Such was the case in the early years of the living wage movement, and for many of the early living wage adopters prospective evidence of this sort was a central element to the public debate. Fortunately, there is now also a broad range of evidence concerning the budgetary and employment impact of local living wage ordinances which draws on the actual experiences of cities that have passed such measures in recent years. I refer to this body of literature as retrospective (or ex post) evidence, and review the salient findings in section four below.

As we shall see, both the prospective and retrospective evidence indicates that for most firms covered by living wage ordinances the costs created by these measures are small, in the range of 1 to 2 percent or less of total firm sales or operating costs. Research also suggests that for a small subset of covered firms these costs can be substantially greater, on the order of 10 percent of sales. Understanding the magnitude of these costs is crucial if we are to accurately gauge how firms will respond to living wage mandates. Although living wage opponents most frequently warn of lay-offs and firm relocations, these are but two of the many ways in which 
businesses can respond to any additional costs associated with living wage mandates. In fact, as I summarize in section five, based on the available evidence it appears that firms are adjusting to living wage-induced costs through a combination of three other means, including raising prices, increasing productivity, and redistributing income within the firm. These alternative adjustment mechanisms appear to have distinct advantages for covered firms within the relevant range of mandated costs, and they may also help explain why most studies to date do not find significant increases in city contract costs following living wage implementation. These conclusions are strikingly similar to the findings put forth in the "new economics of the minimum wage" literature discussed in section two below, and they illustrate the more general point that firms appear to respond to wage-floors in ways that cannot be readily anticipated using theoretical models. I close in section six, synthesizing the available evidence and offering concluding remarks.

\section{Examining Living Wage Effects: Theoretical and Methodological Issues}

The relationship between the minimum wage and employment has been an issue of longstanding and frequently intense controversy. The reasons for this are straightforward. Standard competitive models of the labor market are unambiguous as to the consequences of a binding wage floor. Firms are expected to utilize less low-wage labor, all else constant, which diminishes the economy-wide employment prospects for workers in the lowest tier of the labor market. However, the predictions of the competitive model are just that, predictions, which much be evaluated against available empirical evidence.

Recent work in this area, now known as the "new economics of the minimum wage" literature, has cast serious doubt on the robustness of earlier findings linking minimum wage 
increases with lower employment in the aggregate (e.g. Card et al. 1994; Card and Krueger 1995; Neumark and Wascher 1994). This research has also produced substantial new evidence that firms faced with higher minimum wage mandates do not behave in the manner predicted by competitive models, and that average firm employment does not decline but may in fact increase slightly following minimum wage increases (e.g. Katz and Krueger 1992; Spriggs 1993; Card and Krueger 1994; Card and Krueger 2000). There is also individual-specific evidence that lowwage workers do not face lower employment prospects following minimum wage increases (e.g. Card and Krueger's 1995 re-analysis of Lineneman 1982 and Currie and Fallick 1994; Zavodny 2000).

Both the findings on the economy-wide and firm-level effects of the minimum wage have been subsequently challenged, the debate turning on issues of statistical technique and data quality (Burkhauser et al. 2000; Neumark and Wascher 2000). It is important to note that the preponderance of the individual and firm-level evidence is tilted towards the finding of either no statistically significant employment effect or a small positive one. ${ }^{2}$ However, the larger issue has been well summarized by Richard Freeman: "The debate is over whether modest minimum wage increases have "no" employment effect, modest positive effects, or small negative effects. It is not about whether or not there are large negative effects," (1995, p. 833; emphasis original).

As we will discuss in section five, there are many possible explanations for why individual and firm-level analysis consistently fails to find negative employment effects following minimum wage increases. On a theoretical level one explanation may be that alternatives to the competitive model in fact offer a better description of labor market dynamics than more traditional competitive models. For example, models emphasizing monopsonistic competition admit a variety of possible outcomes in the face of an increased minimum wage, 
including a positive relationship between minimum wages and employment, among other potential equilibria (e.g. Card and Krueger 1995; Bhaksar, Manning, and To 2002; Manning 2003). Others have suggested that efficiency wage models may also be more appropriate than competitive models when characterizing the labor market, highlighting the ways in which higher direct labor costs may be offset by higher productivity and lower indirect labor costs, such as monitoring, recruitment, and training (e.g. Akerlof and Yellin 1986; Stiglitz 1987). ${ }^{3}$

While these theoretical interpretations of recent minimum wage research are a significant advancement in our understanding of labor market dynamics, they unfortunately ignore many "older" explanations of firm adjustments to higher mandated wages, such as those advanced by the post-war institutionalists over fifty years ago. While these scholars did not employ the formalized models that dominate the economics profession today, individuals such as Clark Kerr, Richard Lester, Lloyd Reynolds, and Sumner Slichter anticipated many of the arguments that ground today's models. In the current context, these include such insights as the possibility of a minimum wage increase leaving employment levels unaffected (e.g. Lester 1946, 1947, and 1960), and the deleterious role that labor turnover plays in modern firm management (e.g. Slichter 1919 and 1920). One important commonality among these scholars was an acknowledgement of what Lester called "a range of indeterminacy," not just in wage determination, but also in other areas of firm operations, including the procurement of non-labor inputs and the setting output prices. This approach implicitly recognizes that it is very difficult to identify a real world situation in which all else will be held constant when the minimum wage increases, as the standard competitive model requires. By allowing firms some discretion in areas such as purchasing other inputs and setting output prices, these researchers in practice found themselves considering the range of methods by which firms might adjust to higher wage 
mandates, including such channels as raising prices, increasing sales, changing production techniques, or raising productivity. Changing the level of employment, in this context, becomes only one of many ways in which firms may respond to higher wage mandates. Lester's survey of Southern manufacturers is a prime example of this method of approaching the minimum wage (Lester 1946).

Interestingly, more recent evidence indicates that it is precisely these alternative adjustment channels that firms prioritize in the face of higher minimum wage mandates. For example a little appreciated aspect of Card and Krueger's fast food study in New Jersey and Pennsylvania is that "pretax prices rose 4 percent faster as a result of the minimum-wage increase in New Jersey - slightly more than the increase required to fully cover the cost increase caused by the minimum-wage hike" (Card and Krueger 1995, p. 54). Similar evidence is presented in Aaronson (2001), who finds that restaurant prices in the United States and Canada generally rise with changes in the wage bill, and that these changes are typically concentrated in the first quarter following a minimum wage increase. Understanding how firms use these alternative adjustment channels to cope with increased labor costs following the imposition of binding wage floors may provide the key to reconciling both the recent findings from the new economics of the minimum wage literature as well as those from the prospective and retrospective living wage research reviewed in sections three and four.

While these alternative theoretical and empirical perspectives may indeed prove useful in explaining recent research on the minimum wage, the findings themselves can provide only limited guidance as to the economic impact of living wage ordinances. This is first of all because most living wage laws do not produce the modest wage increases that the "new economics of the minimum wage" literature has traditionally examined. More important, however, is the fact that 
living wage laws have dramatically more limited coverage than traditional minimum wage mandates. Although each ordinance varies substantially, these measures typically cover far less than one percent of a city's labor force. As one example, Pollin and Luce (2000) estimated that by 1999 the Los Angeles (LA), California living wage ordinance would apply to no more than 7,600 workers in the LA labor market. Yet if their calculations are accurate this means that these covered workers would have comprised a tiny segment of the 4.4 million individuals in the Los Angeles area workforce at that time, approximately 0.17 percent. This implies that whatever employment changes may have occurred in the tiny covered sector, their effect is not discernable in the labor market as a whole due to the much larger size of the uncovered segment.

These substantial differences in coverage between minimum and living wage laws make it impossible to utilize the data sets and statistical techniques that are the mainstay of modern labor economics. This conclusion is particularly important, as it calls into question recent research by David Neumark and Scott Adams (Neumark and Adams forthcoming (a) and (b)). In their work the authors apply the popular "difference-in-difference" statistical technique to data from the Current Population Survey (CPS), in an effort to detect the effects of living wage laws on the wages, employment and poverty status of individuals in the bottom decile of wageearners. Unfortunately, their research design suffers from a host of methodological and empirical problems that ultimately invalidates their findings.

For example Neumark and Adams utilize the CPS, which does not allow researchers to identify a respondent's place of employment. Such information is not necessary when studying minimum wage laws, where relatively few labor force participants are exempt from the law and those that are can be readily identified by sector of employment. However employer information is crucial for researchers interested in utilizing publicly available data such as the CPS to study 
living wage ordinances, since the overwhelming majority of low-wage workers are not covered by living wage laws, even in those sectors where covered firms are concentrated.

However, even if it were possible to identify with precision whether individual respondents in the CPS worked for employers covered by a particular living wage law, this survey does not sample a sufficient number of covered workers at the local level for statistically reliable estimation. As one example of this problem, Brenner et al. (2002) calculated that in Los Angeles, with one of the broadest living wage ordinances in the country, there were likely to be only about eight covered workers contained in an annual CPS sample of approximately 5,000 labor force participants. This causes particularly acute identification problems for the "difference-in-difference" statistical technique employed by Neumark and Adams. In their work, the authors propose to "identify" the effects of living wage laws by comparing changes in wages and employment for workers in cities with living wage laws to those in cities without such measures, controlling for other sources of variation. Any difference in the trend between workers in the two different types of cities is attributed to the living wage policy. However as the authors themselves readily acknowledge, living wage ordinances typically cover far less than one percent of the workforce in the cities that adopt them (Neumark and Adams forthcoming a). This implies, almost mechanically, that any changes taking place within living wage cities must themselves be driven by the workers unaffected by living wage laws.

On methodological grounds alone, such a degree of mismeasurement in the key policy variable calls Neumark and Adams' recent findings into question. However, as my colleagues and I have also demonstrated (Brenner et al. 2002), there are substantial empirical problems with the authors' approach to identifying the effects of living wage laws. As one example, Neumark and Adams find that the statistically significant wage and employment effects are concentrated in 
cities where living wage ordinances cover business assistance recipients. They conclude that perhaps the business assistance provisions have had much broader effects that commonly assumed. Unfortunately this explanation does not correspond to actual experience. After interviewing living wage administrators in all the relevant cities, Brenner et al. found that with the exception of one city there have been no economic development projects to which living wage requirements have been applied. ${ }^{4}$ Thus, in practice, living wage laws covering business assistance have been less, not more, comprehensive than those covering city service contracts. This of course does not explain Neumark and Adams' statistical results, it merely invalidates the interpretation of their findings that they advance.

Other, more serious, empirical problems appear to explain why Neumark and Adams find statistically significant wage and employment effects in living wage cities. Of particular note is the close correspondence between living wage implementation and changes in the minimum wage. Indeed, upon examining their data more closely we find that more than half of the living wage observations come from cities where approximately one year after the living wage ordinance was adopted the state or federal minimum wage was increased. Because Neumark and Adams find statistically significant living wage effects only with a one year lag, this creates a severe identification problem. Indeed, one of the great weaknesses of the "difference-indifference" methodology is that it is unable to accurately separate the effects of different policy interventions if their timing coincides. As Brenner et al. (2002) have argued, increases in the minimum wage are a much more plausible source of the effects which Neumark and Adams have attributed to living wage laws, particularly given the large number of workers earning exactly the minimum wage in their sub-sample of the CPS. Ultimately, the combination of these methodological and empirical problems makes it impossible to draw any policy conclusions, 
either positive or negative, from Neumark and Adams' research. Their work, however, does reinforce the methodological imperative to examine the effects of living wage ordinances at the local level, using data more suited to the task. Fortunately, this has been the approach adopted in virtually every other treatment of living wage effects, which we review in the next two sections.

\section{The Economic Impact of Living Wages: Prospective Evidence}

As noted in the introduction, the relatively recent emergence of living wage ordinances necessitated, at least initially, impact analysis using prospective means. The various studies reviewed in this section draw on a range of data sources, including city data on the number and size of affected contracts, surveys of potentially covered firms and workers, and government data on workers and firms including the Census, Current Population Survey, County Business Patterns, and local-area unemployment insurance (ES-202) data. The entire range of prospective work that touches on the cost of living wage laws (including internal city reports, consultant studies and other material) is not reviewed. Instead, the analysis is limited to a subset of this work that meets two criteria: (1) studies that present an estimate of the number of workers likely to be affected by the living wage law under consideration; and (2) provide some sense of the relative cost of each proposal. The former point precludes discussion of many of the internal analyses conducted by city staff or other public officials, while the latter limits the consideration of several other consultant reports such as the analysis of Los Angeles by Sander et al. (1997) and that of Chicago by Tolley et al. (1999). Table 2 summarizes the ten prospective studies which meet these two criteria and which will be discussed in this section. These data will be a prime input in our analysis of how firms are likely to adjust to higher wage mandates, an issue which we take up in section five below. 


\section{[TABLE 2 NEAR HERE]}

\section{Scope of Ordinances}

As shown in Table 1, the living wage rubric has come to encompass a variety of discrete policy initiatives throughout the country, and the measures represented in Table 2 are no exception. In total, these ten ordinances comprise five distinct types of coverage. First is the most prevalent form of living wage policy, which placing wage requirements on city service contracts. This is a component of the living wage measures in Los Angeles, Miami-Dade County, San Jose, Detroit, and San Francisco. Both the San Francisco and New York measures also cover workers in the second category of social service provision, particularly homecare and childcare, while Los Angeles, San Jose, and Detroit also cover workers in the third category of economic development assistance. The living wage ordinances in Los Angeles, San Francisco, Oakland, and New York extend living wage coverage to the fourth category of lessees and other tenants on city property, while the Santa Monica and New Orleans living wage measures comprise the fifth category of geographically-based wage policies. Each of these measures also differs in terms of the provision of other benefits, with all the laws except the New Orleans city-wide minimum wage proposal offering some sort of health benefits coverage. In addition, the living wage ordinances in Los Angeles, San Jose, Oakland, and Santa Monica also making provisions for a minimum number of paid days off.

Turning to the mandated wage increases, as can be seen from the second column of Table 2, these measures vary widely in this regard as well. The range spans the relatively modest 19 percent increase represented by the $\$ 6.15$ per hour minimum wage proposed for the city of New Orleans, to the 117 percent increase over the California minimum wage which the $\$ 12.50$ per 
hour proposal for the city of San Jose represents. Taken together, the ordinances stipulate, on average, a 71 percent increase over the prevailing minimum wage.

The third column of Table 2 presents estimates of the number of workers likely to benefit from each living wage measure. Here too, there is wide variation among the different types of living wage measures, with the number of estimated beneficiaries ranging from as low as 1,561 in San Jose, to as high as 62,000 in New York City. By and large the number of workers covered by each ordinance corresponds to the breadth of coverage in each case. For example, the citywide minimum wage proposal in New Orleans was expected to covers close to 47,000 individuals - more than 10 percent of the city's population. The San Jose living wage measure, when applied to the 235 firms holding eligible city service contracts is projected to cover only 1,561 individuals - a mere 0.2 percent of the San Jose population. ${ }^{5}$ One anomaly appears to be the case of New York, where approximately 62,000 individuals are expected to gain from the proposed living wage law. While this figure is much higher, in absolute terms, than any of the other cities under consideration, upon closer inspection it appears to be roughly in line with the scope of the most comparable ordinance under consideration here, namely San Francisco's living wage law. ${ }^{6}$

\section{Total Costs Relative to Economic Activity}

We now turn our consideration to the key finding from each of the 10 studies presented in the fourth column of Table 2, the estimate of total expected costs relative to some measure of firm economic activity. Because of the range of data and methods employed in these studies, the measure of economic activity varies across the cases listed in the table. For San Jose, Oakland, Santa Monica, and New York the total cost of the living wage ordinance was measured against firm revenue, with Los Angeles differing only slightly in that firm output (the value of sales plus 
inventory) was used for relative calculations. For the estimates in Miami-Dade County, the city of San Francisco, and Detroit, the total cost of covered contracts was used as the metric for measuring living wage costs, while studies in New Orleans and the Port and Airport of San Francisco compared total costs to firm operating costs (production costs net capital costs).

As we see from Table 2 , these cost estimates display a fairly wide range, from 0.3 percent of firm revenue for New York City subsidy recipients, to 10.4 percent of gross receipts for luxury hotels in Santa Monica California. Several factors influence the magnitude of these relative costs. The first is obviously the size of the mandated wage increase, with more modest wage increases generating correspondingly modest average cost increases. The most prominent example of this is the case of New Orleans, where the 19 percent increase in the minimum wage was found likely to elicit a 0.9 percent increase in operating costs on average. At the other extreme is the case of San Jose, where the living wage level initially proposed was a full 117 percent above the California minimum wage. This relatively high living wage level helps explain why the average cost increase for San Jose city contractors was approximately 3 percent, as compared to the 1.5 percent average cost increase anticipated for Los Angeles city contractors, who faced a 71 percent increase over the operative minimum wage.

A second factor that influences the magnitude of the relative cost estimates in Table 2 is the incorporation of a host of indirect costs not mandated by the living wage ordinance, but likely to occur once the law is implemented. These non-mandated costs are part of the total cost calculation in the estimates for Los Angeles, New Orleans, Santa Monica, and the Port and Airport of San Francisco and Oakland. The distinction between the direct costs mandated by living wage ordinances, such as the higher wages and associated payroll taxes, and other nonmandated costs likely to result from the law is an important one. As has been well established in 
the minimum wage literature, higher wage mandates exert an influence on wages beyond those directly mandated to receive pay raises.

Commonly referred to as "ripple effects" these non-mandated increases are a wellestablished empirical phenomenon, despite some ambiguity as to their precise magnitude. In the context of the minimum wage, available research indicates that ripple effects are typically much smaller in proportional terms than mandated increases, and they do not reach very far up the wage distribution, perhaps no more than $\$ 1$ to $\$ 2$ above the newly mandated minimum wage (e.g. Spriggs 1993; Card and Krueger 1995; Lim 2002). Of course, establishing the magnitude of any ripple effects that may result from a living wage is necessarily a more speculative exercise than the estimation of its direct costs. However, in the five cases where ripple effects are estimated, they display a reasonable degree of consistency, ranging from 11 percent to 26 percent of total costs. Clearly effects of this size are large enough to influence estimates of total relative cost, and any estimates which include these non-mandated costs will be correspondingly larger than those focused only on direct costs alone.

Finally, a third major factor influencing the magnitude of relative costs is the degree to which living wage coverage is concentrated in relatively low-wage industries. When such concentrations occur, relative cost figures will be slightly higher on average, in the range of four percent of revenues or operating costs. This can be seen, for example, in cost estimates for the ports of Oakland and San Francisco where the living wage ordinance falls most heavily on the restaurant and retail sectors. There may also be sectors, such as Santa Monica's hotels and restaurants, where the relative costs exceed even these figures. What is equally important to note, however, is that many, if not most firms covered by living wage ordinances will face much more modest cost increases. One example of this is the case of New York City subsidy recipients - 
large firms concentrated in high wage industries such as financial services, media, and manufacturing - where cost increases are much more modest than the figures discussed above, on the order of 0.3 percent of firm revenue. Indeed, research in Los Angeles has demonstrated that, in fact, the vast majority of firms covered by that city's living wage law fall into this "low impact" category. According to Pollin and Luce (2000) a full 86 percent of covered businesses were anticipated to have cost increases of one percent or less. Thus, while it is important to acknowledge the much larger impact that living wage laws will have on a small subset of covered firms, the experience of these firms appears to be the exception and not the rule.

To summarize, despite the vastly different scope of each living wage measure, coupled with the range of methodologies and data utilized to estimate the economic impact in each case, there is a striking degree of consistency in the projected cost figures for each city. Most cost estimates fall into the range of one to two percent of firm revenue, or two to four percent of covered contract value. There are notable exceptions to these averages, such as the hotels and restaurants of Santa Monica, expected to face cost increases of approximately 10 percent of revenue. However even in the Santa Monica case if we calculate the average cost increase for affected firms other than hotels and restaurants we find that these businesses are likely to face a cost increase of approximately 2.2 percent. Establishing the magnitude of likely cost increases is crucial if we are to accurately gauge how firms will respond to living wage mandates. Before turning to these questions, however, I examine evidence that draws on the actual experiences of cities that have passed living wage measures in recent years.

\section{The Economic Impact of Living Wages: Retrospective Evidence}


This section analyzes the impact that living wage laws have had on city contract costs and bidding patterns. As noted earlier, one of the principle fears voiced by opponents to living wage laws is that these measures have negative financial implications for city budgets. It is argued that if living wage laws generate substantial costs, particularly for city service contractors, these costs will ultimately be passed back to city governments. Such costs could leave cities with the unpleasant choice of either reducing the level of existing city services or raising additional revenue through higher taxes. A second concern is that living wage laws may cause some bidders to reconsider the desirability of city contracting, adversely affecting the competitiveness of the bidding process for city service contracts.

\section{Changes in City Contract Costs}

The evidence considered with regard to these questions comes from two sources: information reported by cities themselves in official documents or in interviews with scholars; and evaluations of city records conducted by independent researchers. In terms of the independent assessment of the effects of living wage laws, there are three major evaluations. Two analyze Baltimore MD, one of the first cities in the country to pass a living wage law. These reports compare approximately two dozen contracts before and after the living wage law went into effect (Weisbrot and Sforza Roderick 1996; Niedt et al. 1999). The third study considers similar evidence on changes in contract costs following living wage implementation in three New England cities: Hartford, CT, New Haven, CT, and Boston, MA (Brenner and Luce 2003). These estimates are presented in Table 3, which also provides figures from local officials concerning the changes in contract costs following living wage implementation. These include information on several social service contracts in Dane County, WI and San Francisco, CA (Elmore 2003) and the 31 covered contracts in Corvallis, OR (Brewer 2001). 


\section{[TABLE 3 NEAR HERE]}

Turning to the evidence, the most important point is that cities have had a wide variety of experiences with living wage laws as they relate to city service contract costs. For example, in the Baltimore case, both studies found only modest increases in nominal contract costs (in the aggregate) after the implementation of the living wage law. Weisbrot and Sforza-Roderick (1996) reported a nominal increase of less than a quarter of a percent in the total cost for all 19 contracts in their study following living wage implementation, while Niedt et al. (1999) incorporating an additional year's worth of data and several additional contracts, found a nominal increase of 1.2 percent for the 26 contracts they analyzed. ${ }^{7}$ In both cases, these nominal increases were lower than the rate of inflation, implying that in real terms city contract costs decreased in Baltimore following the implementation of that city's living wage law. This experience of declining real contract costs is not unique to Baltimore. As is evident from Table 3, both Boston, MA and New Haven, CT also witnessed a decline in the real value of covered contracts, and the nominal increase in contract costs for covered social services in Dane County, WI and San Francisco, CA was below the rate of inflation in each locality.

Although aggregate costs declined in real terms in each of these cases, it is important to note that many of these studies documented substantial variation across individual contracts. For instance, one small janitorial contract in Baltimore increased in nominal terms by 47.1 percent, while the contract for summer food services declined by 11.6 percent. Meanwhile the contract for bus services, by far the largest covered contract in Baltimore, rose by only 2.1 percent (Niedt et al. 1999). Given this wide range of experience within cities, it is not surprising that there are also substantially different experiences between cities, with several reporting rising aggregate contract costs following living wage implementation. In Corvallis, OR, the Finance Director 
reported a 9.1 percent increase in costs for contracts under the living wage mandate. These increases were sharpest for bus repair and maintenance (34\%), for custodial services (21\%), and for the humane society contract (17\%) (Brewer 2001). Brenner and Luce (2003) also report cost increases of this magnitude for the city of Hartford, CT, where the cost of security guard services and temporary office help together rose 33.4 percent following living wage implementation. One important characteristic of these services in Hartford is that they are bid on the basis of an hourly rate, with an estimated but not guaranteed number of hours of service to be performed over the life of the contract. The authors argue that soliciting bids on the basis of an hourly rate is causally linked to the higher contract cost increases witnessed in Hartford. They conclude that this method of bidding blunts the very forces of competition that have held down cost passthroughs in other cities.

Elmore (2003) also records a wide range of experience in his review of living wage implementation in 13 cities. He notes first that in each case he considered, city officials reported higher service contract costs in absolute dollar terms, although these increases range from very slight (approximately $\$ 9,000$ in Ypsilanti, MI) to quite substantial (over $\$ 3.7$ million for all human service contracts in San Francisco, CA). Elmore also documents the enormous variation in cost increases among individual contracts. He describes cases where contract costs rose by a substantial amount, such as a janitorial contract covered by Warren MI's living wage law which rose by $22 \%$, as well as cases where contract costs declined in absolute terms, as with three human service contracts in Dane County, WI. This variation only serves to underscore our earlier observation that many factors influence city contract costs, with the living wage ordinance being only one among them.

\section{Changes in Bidding Patterns}


We next turn to the effect of living wage laws on bidding patterns. Here too city experiences vary widely. In Baltimore, for the 14 contracts that were re-bid (as opposed to renewed) following living wage implementation, only three displayed an increase in the number of bidders, while eight saw a decrease. In total, there were 93 bids tendered for these fourteen contracts prior to the living wage, and only 76 bids tendered following the law (Weisbrot and Sforza-Roderick 1996). These figures suggest that Baltimore's living wage law may have had an impact on the number of bidders willing to compete for city contracts following living wage implementation. On the other hand, Brenner and Luce (2003) suggest that the effect of living wage laws on bidding patterns can sometimes have the opposite effect. They find, for example, that covered contracts in Hartford saw a 20 percent increase in the number of bids tendered following living wage implementation, while competitively bid contracts in Boston saw no change in the number of bids tendered. By contrast, New Haven saw the total number of bids tendered decline by 3 , from 32 to 29 .

Regardless of the precise quantitative effect of living wage laws on bidding patterns, results from Elmore's (2003) study indicate that many city officials view living wage laws as at least compatible with, if not conducive of, a more competitive bidding process. As one example, a policymaker in Ypsilanti Township, MI remarked that following living wage implementation, the Township's major contracts had "more bidders than ever before, at even better rates" (Elmore 2003, p. 15) This city official attributed the lower bids to the living wage law, noting that the ordinance subjected contracts to a competitive bidding process with fixed wage and benefit requirements, which in turn forced bidders to "be tighter and provide less of a profit margin" (ibid). Elmore also documents a similar experience in Alexandria, VA, where city officials stated that "[t]here have been some competitive advantages to re-bidding, we have seen 
some incumbents who lost on the second go-round, and it may be due to the bidding process" (ibid). Although fewer cities have examined this issue directly, there is some evidence that bidding has not been adversely affected by living wage laws. For example, the Corvallis, OR Finance Director reported that although several firms indicated they would not bid on city business because of the living wage, in fact, every vendor contacted has submitted a bid, and "and the bids have continued to be competitive" (Brewer 2001, p. 1). Similarly, in Hayward, CA the Acting Finance Director reported that all contracts have remained competitively bid, and that it was the "staff's opinion that productivity and service quality has not been adversely affected" (Finance Director's Office 2000, p. 3).

Upon reflection, it is not surprising that living wage laws have had a relatively benign effect on the bidding process for city service contracts. Available evidence indicates that when savings accrue from the contracting out services, the majority of these savings are the result of providing lower wages and benefits to workers performing the newly privatized services (Kettl 1993; López-de-Silanes 1997). In such a context living wage ordinances can reduce the ability of some bidders to undercut their competition by lowering wage and benefit levels. Thus, a living wage law has the effect of "leveling the playing field," forcing contractors to compete with one another along other dimensions such as service quality. Similar sentiments among city officials in New England are documented by Brenner and Luce (2003).

Several conclusions emerge from the evidence discussed above. First, although cities have had a wide range of experiences with living wage laws, the preponderance of evidence indicates that living wage ordinances are unlikely to cause large increases in city contract costs. There are, of course, specific contracts or types of services for which cost increases will occur, but even in these cases the method of bid submission and the competitiveness of the bidding 
process can modulate cost pass-throughs to the city. With regard to the bidding process itself, here, too, the affects of living wage laws are highly variable. There are some instances - such as in Baltimore - where living wage ordinances appear to shrink the pool of willing bidders, although there are also examples where living wage ordinances appear to have strengthened the bidding process. Available evidence indicates that city officials do not see these measures as an impediment to competitive bidding, and may, in fact, consider them an inducement. This heterogeneity in bidding experiences also serves to underscore the fact that the living wage ordinance is only one of many factors influencing the competitiveness of city procurement. It also reinforces the conclusion drawn earlier that firm behavior in the face of higher wage mandates is not nearly so straight-forward as often assumed in the realm of theory.

\section{How Do Firms Adjust to Living Wage Mandates?}

Thus far, we have gained an understanding of the range of costs businesses are likely to experience when faced with living wage mandates as well as a sense of how city service contract costs and bidding practices have been affected by living wage laws. I will now try draw out the links between these two elements, turning attention to the various means by which covered firms can confront higher wage mandates. The objective is to briefly assess which of the various adjustment mechanisms firms will deploy when faced with living wage-induced cost increases.

The assessment is based on the relative magnitude of these costs, the range of outcomes observed at the city-level, and, where possible, direct evidence on firm behavior following living wage implementation.

When reviewing how firms respond to wage floors, two types of adjustments - layoffs and relocations - are the most frequently discussed. Yet these are not the only options firms have 
at their disposal, nor do they appear to be the most likely means by which firms address the higher labor costs associated with living wage laws. Indeed there are three other adjustment channels that firms can employ: raising prices; increasing firm productivity; and increasing the share of firm income going to low wage workers. Available evidence indicates that adjustment is more likely to occur through some combination of these three mechanisms, as they can be accomplished more readily and at lower costs than either layoffs or firm relocation.

\section{Raising Prices}

For most firms covered by living wage laws, the process that would be least costly and disruptive would be to simply raise prices to reflect increased costs. But a firm's ability to raise prices depends on the competitiveness of the market in which they operate as well as how price sensitive their customers are (i.e. on the elasticity of product demand). If we first consider city service contractors, it is important to recognize that these firms will typically face at least one serious competitor during the bidding process (Rehfuss 1989). If living wage costs are modest, on the order of 1 to 2 percent, bid prices from covered vendors may not be affected, as these firms are unlikely to sacrifice the reliable income stream and health margins associated with government contracts over such modest changes in operating costs. This helps explain why so many cities have not witnessed rising contract costs following living wage implementation, since most covered vendors fall into this category.

If living wage costs are more substantial, however, it is likely that firms will press the city to absorb some or all of these costs. The absolute number of these "high impact" firms appears to be small. For example, Pollin and Luce (2000) estimate that roughly seven percent of covered contractors in Los Angeles faced cost increases greater than 10 percent. It is important to recognize a significant portion of the higher costs can be absorbed by the firm through other 
means, obviating the need to pass them back to city governments. However, it is nonetheless true that even full pass-through of such costs is a small fraction of the total city budget -0.2 percent in the Los Angeles example discussed above. Cities can also use competition (or the threat of it) to inhibit full cost pass-through, as illustrated by the experience in the city of Pasadena, CA. There, covered vendors agreed to absorb between 40 to 55 percent of the higher costs associated with living wage if the city extended their current service agreements rather than put them out for competitive bidding. There are also ways in which cities can modulate cost pass-throughs by changing the structure of contracting. One example of this includes Multnomah County, OR, where the living wage policy increased service delivery costs by 27 percent. However, the county was able to limit their contract cost increase to only 5 percent by consolidating three formerly separate janitorial services (Facilities and Property Management Division, n.d.). Brenner and Luce (2003) have also showed that pass-throughs are highest for contracts bid on a unit-cost basis (sometimes known as "cost-plus" bidding), indicating that cities can also limit cost pass-throughs by changing the terms on which bidding occurs. ${ }^{8}$

What about those firms not directly contracting with city governments? The largest set of these firms operate concessions on city property, selling goods and services to the public in airports, ports, and other public facilities. While their ability to pass along higher costs will ultimately be governed by their demand elasticities, it is important to stress that these firms operate in highly circumscribed markets, in places such as airports and sports arenas. ${ }^{9}$ To the extent that there are few readily available alternatives, this strengthens their ability to pass costs on to consumers in the form of higher prices. Available evidence also indicates that price increases on the order of 3 to 4 percent are within a range which does not undermine demand (Card and Krueger 1995). 


\section{Productivity and Redistribution}

In examining these two adjustment channels, we start from the premise that covered firms are experiencing productivity gains on the order of 1 percent per year prior to living wage implementation. This is a reasonable assumption, given that it is half the annual average for all U.S. businesses over the last full business cycle. It also implies that for most covered firms a large portion - if not the entirety - of living wage costs can be absorbed with productivity increases that are the normal course of business development. There are at least two reasons, however, that we would expect firm productivity to grow faster following living wage implementation. First, firms are likely to be more attentive to potential cost saving measures, as well as more open to changes in work organization, that could also compensate for the slightly higher labor costs they now face when doing business with the city. Second, the higher wages associated with living wage laws are also likely to have a salutary effect on employee performance. In the latter case, the benefits of higher wages have several sources. For example, as the efficiency wage literature discussed in section two has made clear, paying higher wages is likely to increase the individual effort and motivation of those workers receiving raises. These higher wages are also likely to reduce other less appreciated labor costs, such as turnover and absenteeism. While their precise costs are difficult to quantify, the evidence is clear that living wage laws can dramatically effect on both turnover and absenteeism. The most striking example of these effects is from the San Francisco Airport, where Reich et al. (2003) have shown that turnover fell by up to 80 percent for several low wage occupations following living wage implementation. Similarly, Howes (2002) estimates that the San Francisco living wage law contributed to a 20 percent decline in turnover for covered homecare workers. Turnover reductions of this magnitude are not likely to generate savings sufficient to fully offset living 
wage costs. However they will no doubt ease the financial pressure which otherwise would spur firms to pass such costs back to the city in the form of higher contract costs.

Of course, channeling productivity increases into higher wages for low-paid employees entails a redistribution of income within covered firms. By the same token, for most firms this adjustment would occur only once, in the first year of living wage implementation. Subsequent productivity increases could be absorbed by the firm in whatever manner they deem appropriate, with lower paid workers still receiving a living wage.

\section{Layoffs and Firm Relocation}

There are few reasons to expect that living wage laws will lead to layoffs or other negative employment consequences. This is sensible given the modest costs for most firms covered by living wage laws. However, even for "high impact" firms, there are many reasons to believe that some combination of prices, productivity, and redistribution will preclude firms shedding labor to comply with living wage laws. Recent empirical evidence also supports these conclusions. Three examples stand out. At the San Francisco airport, Reich et al. (2003) report that total employment in covered firms increased by 15 percent following living wage implementation. Brenner and Luce (2003) report that firms covered by the Boston living wage ordinance also saw employment increase by 15 percent over pre-living wage levels. Howes (2002) estimates that the number of homecare workers covered by San Francisco's living wage law increased by 54 percent. In the Boston case, another particularly important finding is that employment grew faster for those firms who were force to raise wages to comply with Boston's living wage law than for those who did not (Brenner and Luce 2003). On a full-time equivalent basis, employment growth was nearly 50 percent higher for firms raising wages than for those who did not, with the bulk of this increase resulting from firms shifting part-time workers to full- 
time schedules. While this does not suggest that higher wage floors "caused" higher employment, it does demonstrate that the two are at least compatible, particularly in a context of rapid economic growth. It also bolsters the contention that other macroeconomic factors are decisive in determining the precise level of employment.

When considering relocation, there are few reasons to believe that living wage laws will create substantial incentives for firms to move out of their current geographic area. First, as noted many times before, the magnitude of living wage costs are very modest for most covered firms, making relocation infeasible on a purely cost basis. Of even greater consequence is the fact that most living wage laws regulating city service contracting apply their wage mandates to firms regardless of their location, so firms are unable to avoid compliance by relocating out of a given locality. Relocation incentives pose a more serious issue for some geographically-based living wage measures, such as the Santa Monica and New Orleans living wage proposals. However, even in these two cases the available evidence indicates that that the most heavily impacted businesses - such as the hotels and restaurants that comprise the core of both cities' tourism industry - are also heavily tied to their current locations (Pollin and Brenner 2000; Pollin et al. 2002). Relocation will no longer allow firms to compete in the tourist market, which is the core of their current operations. This, in turn, implies that the costs of such a measure will likely exceed the expected benefits. ${ }^{10}$ Thus, on balance, the evidence indicates that due to the specific manner in which living wage laws function, firms under their mandate will find adjustments through some combination of prices, productivity, and redistribution preferable to the more disruptive options of layoffs and relocation.

\section{Conclusion}


This paper has reviewed the economic effects of local living wage ordinances, drawing on a range of prospective and retrospective research. We have seen that these laws are highly specific, localized measures, which precludes using the national data sets and statistical techniques that are the mainstay of modern labor economics can offer us little insight into living wage dynamics. We have also seen that, much like recent results for more conventional minimum wage measures, the evidence suggests that firms respond to living wage laws in ways not readily anticipated by competitive models of the labor market. There appear to be several explanations for this empirical regularity. First, most firms covered by living wage laws experience only modest costs - on the order of 1 to 2 percent of total economic activity - which carries with it the implication that layoffs or firm relocation are likely to be far more disruptive and costly than other channels of adjustment. For some firms, the costs associated with living wage compliance are much greater: 10 percent or more of economic activity. However even for this set of firms, the evidence suggests that some combination of price increases, productivity enhancements, and internal redistribution are the primary means by which they adjust to these measures.

While these alternative adjustment measures make it unlikely that firms will shed workers or move from their existing base of operations, they nonetheless have potentially serious implications for city budgets. While there is clearly evidence that living wage laws raise the price of certain city service contracts, there is also a preponderance of evidence that this is not a generalized phenomenon. Indeed, both internal adjustments such as productivity increases or redistribution, as well as the external force of competition, appear to preclude the full passthrough of living wage-related costs to city budgets. While it is important to realize that even full cost pass-through by high impact firms is a negligible percentage of city finances - less than 0.2 
percent for our example of Los Angeles - it is also important to acknowledge that cities can affect the degree to which firms pass along living wage costs by both altering the terms for certain services, as well as changing bidding procedures for others. The weight of the accumulated evidence indicates that living wage laws have an important impact on the living standards of a modest number of beneficiaries, while diffusing the costs broadly among city service contractors and the general public. 


\section{References}

Aaronson, D. (2001) "Price Pass-Through and the Minimum Wage." Review of Economics and Statistics 83 (1): 158-69.

Akerlof, G. and J. Yellen. (1986) Efficiency Wage Models of the Labor Market. Cambridge, UK and New York, NY: Cambridge University Press.

Bhaskar, V., A. Manning, and T. To. (2002) "Oligopsony and Monopsonistic Competition in Labor Markets." Journal of Economic Perspectives 16 (2): 155-174.

Benner, C. and R. Rosner. (1998) "Living Wage: An Opportunity for San Jose," August, San Jose, CA: Working Partnerships.

Brenner, M.D. and S. Luce. (forthcoming) "The Effect of Living Wage Laws in New England." Amherst, MA: Political Economy Research Institute Research Report.

Brenner, M.D., J. Wicks-Lim and R. Pollin. (2002) "Measuring the Impact of Living Wage Laws: A Critical Appraisal of David Neumark's 'How Living Wage Laws Affect LowWage Workers and Low-Income Families'.” Amherst, MA: Political Economy Research Institute Working Paper \# 43.

Brewer, N. (2001) CMC 1.25 Living Wage Ordinance Review. Corvallis, OR, Finance Director's Office.

Brocht, C. (2000) "The Forgotten Workforce: More Than One in 10 Federal Contract Workers Earn Less Than a Living Wage.” November, Washington, DC: Economic Policy Institute Briefing Paper.

Burkhauser, RV., K.A. Couch, and D.C. Wittenburg (2000) “A Reassessment of the New Economics of the Minimum Wage Literature with Monthly Data from the Current Population Survey," Journal of Labor Economics 18 (4): 653-80.

Campbell, C.M. (1993) "Do Firms Pay Efficiency Wages? Evidence with Data at the Firm Level." Journal of Labor Economics 11 (3):442-470.

Cappelli, P. and K. Chauvin (1991) "An Interplant Test of the Efficiency Wage Hypothesis." Quarterly Journal of Economics 106 (3):769-87.

Card, D., L. Katz, and A.B. Krueger (1994) "Comment on David Neumark and William Wascher, 'Employment Effects of Minimum and Subminimum Wages: Panel Data on State Minimum Wage Laws."' Industrial and Labor Relations Review, 48 (3): 487-96.

Card, D. and A.B. Krueger. (1994) "Minimum Wages and Employment: A Case Study of the Fast-Food Industry in New Jersey and Pennsylvania." American Economic Review 84 (4):772-793. 
-. (1995) Myth and Measurement: The New Economics of the Minimum Wage. Princeton, NJ: Princeton University Press.

- (2000) "Minimum Wages and Employment: A Case Study of the Fast-Food Industry in New Jersey and Pennsylvania: Reply.” American Economic Review 90 (5):1397-1420.

Citro, C.F., and R.T. Michael, eds. (1995) Measuring Poverty: A New Approach. Washington, DC: National Academy Press.

City Manager's Office. (2000) “Living Wage Ordinance - One Year Status.” Pasadena, CA.

Currie, J., and B.C. Fallick (1994) "The Minimum Wage and the Employment of Youth: Evidence from the NLSY." Unpublished paper. Los Angeles: UCLA Department of Economics. subsequently published in Journal of Human Resources, Spring 1996, 31 (2): 404-28.

Elmore, A. (2003) "Contract Costs and Economic Development in Living Wage Localities: A Report from Cities and Counties on the Impact of Living Wage Laws on Local Programs.” New York, NY: Brennan Center for Justice.

Employment Policies Institute. (1998) “The Baltimore Living Wage Study: Omissions, Fabrications and Flaws." October, Washington, DC: The Employment Policies Institute.

Facilities and Property Management Division. (n.d.) "Report on Living Wage and Benefit Project." Multnomah County, OR.

Finance Director’s Office. (2000) “Living Wage Ordinance Report”. Hayward, CA.

Freeman, R. (1995) "What Will a 10\%...50\%...100\% Increase in the Minimum Wage Do?" Industrial and Labor Relations Review 48 (4): 830-834.

Freeman, R.B. and J.L. Medoff. (1984) What Do Unions Do? New York, NY: Basic Books.

Howes, C. (2002) "The Impact of a Large Wage Increase on the Workforce Stability of IHSS Home Care Workers in San Francisco County." New London, CT: Connecticut College Department of Economics.

Katz, L. and A.B. Krueger. (1992) "The Effects of the Minimum Wage on the Fast Food Industry." Industrial and Labor Relations Review 46 (1):6-21.

Kettl, D. F. (1993) Sharing Power: Public Governance and Private Markets. Washington, DC, The Brookings Institution.

Krueger, A.B. and L.H. Summers. (1988) "Efficiency Wages and the Inter-Industry Wage Structure.” Econometrica 56 (2):259-93. 
Lester, R. 1946. "Shortcomings of Marginal Analysis for Wage-Employment Problems." American Economic Review 36 (1):63-82.

—. 1947. "Marginalism, Minimum Wages and Labor Markets." American Economic Review 37 (1):135-148.

—. 1960. "Employment Effects of Minimum Wages." Industrial and Labor Relations Review 13 (2):254-264.

Levine, D. 1992. "Can Wage Increases Pay for Themselves? Tests with a Production Function." Economic Journal 102 (September):1102-15.

Lim, J. 2002. "How Big Are Ripple Effects from Minimum Wage and Living Wage Increases?" Paper presented at the Allied Social Sciences Association, Atlanta, GA.

Linneman, P. (1982) "The Economic Impacts of Minimum Wage Laws: A New Look at an Old Question.” Journal of Political Economy 90 (3): 443-69.

López-de-Silanes, F., A. Shleifer, and R.W. Vishny (1997). "Privatization in the United States." Rand Journal of Economics 28 (3): 447-471.

Luce, S. (2002) ““The Full Fruits of our Labor”: The Rebirth of the Living Wage Movement." Labor History 43 (4):401-409.

—. (2003) "Fighting For a Living Wage: The Politics of Implementation." Amherst, MA: unpublished book manuscript.

Manning, A. (2003) Monpsony in Motion. Cambridge and New York: Cambridge University Press.

Neumark, D. and W. Wascher (1994) "Employment Effects of Minimum and Subminimum Wages: Reply to Card, Katz, and Krueger," Industrial and Labor Relations Review 47 (3): 497-512.

Neumark, D. and S. Adams (forthcoming-a) "Detecting Effects of Living Wage Laws." Industrial Relations.

—. (forthcoming-b) “Do Living Wage Ordinances Reduce Urban Poverty?” Journal of Human Resources.

Neumark, D. and W. Wascher. (2000) "Minimum Wages and Employment: A Case Study of the Fast-Food Industry: Comment." American Economic Review 90 (5):1362-96.

Niedt, C., G. Ruiters, D. Wise, and E. Schoenberger. (1999) “The Effects of The Living Wage In Baltimore.” Washington, DC: Economic Policy Institute. 
Nissen, B. (1998) “The Impact of a Living Wage Ordinance on Miami-Dade County,” October, Miami, FL: Florida International University Center for Labor Research and Studies.

Pollin, R. and S. Luce. (2000) The Living Wage: Building a Fair Economy. New York: The New Press.

Pollin, R., and M.D. Brenner. 2000. “Economic Analysis of Santa Monica Living Wage Proposal.” Amherst, MA: Political Economy Research Institute Research Report \# 2.

Pollin, R. M. Brenner, and S. Luce. 2002. "Intended versus Unintended Consequences: Evaluating the New Orleans Living Wage Ordinance." Journal of Economic Issues 36 (4): $843-875$.

Preamble Center (1999) “Baltimore's Living Wage: Response to Critics," Washington, D.C.: The Preamble Center.

Raff, D. and L. Summers. (1987) “Did Henry Ford Pay Efficiency Wages?” Journal of Labor Economics 5 (4):S57-S86.

Rehfuss, J.A. 1989. Contracting Out in Government. San Francisco: Jossey-Bass.

Reich, M., P. Hall, and F. Hsu. (1999a) "Living Wages and the San Francisco Economy: The Benefits and the Costs." June, Berkley, CA: University of California, Berkeley: Institute of Industrial Relations.

Reich, M., P. Hall and F. Hsu. (1999b) "Living Wages at the Airport and Port of San Francisco: The Benefits and Costs," October, Berkeley, CA: University of California, Berkeley: Institute of Industrial Relations.

Reich, M., P. Hall, and K. Jacobs. (2003) "Living Wages and Economic Performance: The San Francisco Airport Model.” Berkeley, CA: University of California, Berkeley: Institute of Industrial Relations.

Reynolds, D., (1999) “The Impact of Detroit's Living Wage Ordinance," September, Detroit, MI: Wayne State University Labor Studies Center.

Slichter, S. (1919) “The Management of Labor.” The Journal of Political Economy 27 (10):813839.

-. (1920) "The Scope and Nature of the Labor Turnover Problem." Quarterly Journal of Economics 34 (2):239-245.

Sonn, P., Bernhardt, A., and J. Parrott, J. (2002) “The New York City Living Wage Law" September, New York, NY: Brennan Center for Justice and Fiscal Policy Institute. 
Spriggs, W.E. (1993) "Changes in the Federal Minimum Wage: A Test of Wage Norms." Journal of Post-Keynesian Economics 16 (2):221-39.

Stiglitz, J. (1987) “The Causes and Consequences of the Dependence of Quality on Price." Journal of Economic Literature 25 (1):1-48.

Tolley, G., P. Bernstein, and M.D. Lesage. (1999) "Economic Analysis of a Living Wage Ordinance" Chicago, IL: RCF Consulting.

Weisbrot, M. and M. Sfroza-Roderick. (1996) "Baltimore's Living Wage Law: An Analysis of the Fiscal and Economic Costs of Baltimore City Ordinance 442," Washington, DC: The Preamble Center.

Williams, D. and R. Sander. (1997) “An Empirical Analysis of the Proposed Los Angeles Living Wage Ordinance.” Los Angeles, CA: University of California Los Angeles School of Law.

Zabin, C., M. Reich and P. Hall, (1999) "Living Wages at the Port of Oakland,” December, Berkeley, CA: University of California, Berkeley: Institute of Industrial Relations.

Zavodny, M. (2000) "The Effect of the Minimum Wage on Employment and Hours." Labour Economics 7 (6): 729-50. 
Table 1: Number of Living Wage Ordinances with Selected Coverage

\begin{tabular}{lcc}
\hline $\begin{array}{l}\text { Ordinances that cover: } \\
\text { Service contractors }\end{array}$ & $\begin{array}{c}\% \\
\text { of total }\end{array}$ \\
\hline $\begin{array}{l}\text { Recipients of economic } \\
\text { development assistance }\end{array}$ & 74 & $77 \%$ \\
$\begin{array}{l}\text { Subcontractors } \\
\text { City employees }\end{array}$ & 31 & $38 \%$ \\
$\begin{array}{l}\text { Concessionaires, lessees, or } \\
\text { tenants }\end{array}$ & 21 & $32 \%$ \\
$\begin{array}{l}\text { Airports } \\
\text { Private employers in } \\
\text { geographically-based zone }\end{array}$ & 9 & $92 \%$ \\
Total ordinances & 4 & $4 \%$ \\
\hline Source: Luce $(2003)$. & $3 \%$ \\
\hline
\end{tabular}

Source: Luce (2003).

Note: Includes ordinances passed through December 2002, with the exception of cities for which copies of the ordinance could not be obtained. The table also does not include university living wage ordinances. 


\section{Table 2: Economic Impact of Various Living Wage Ordinances Prospective Evidence}

\begin{tabular}{|c|c|c|c|c|}
\hline $\begin{array}{l}\text { City } \\
\text { (Source) }\end{array}$ & $\begin{array}{l}\text { Wage Increase as a } \\
\text { Percentage of the } \\
\text { Minimum Wage }\end{array}$ & $\begin{array}{l}\text { Workers } \\
\text { Covered }\end{array}$ & $\begin{array}{c}\text { Total Cost Relative } \\
\text { to Economic } \\
\text { Activity } \\
\end{array}$ & $\begin{array}{l}\text { Relative } \\
\text { Measure }\end{array}$ \\
\hline $\begin{array}{l}\text { Los Angeles, CA } \\
\text { (Pollin and Luce 2000) }\end{array}$ & $71 \%$ & 7,626 & $1.5 \%$ & $\begin{array}{l}\text { Firm } \\
\text { Output }\end{array}$ \\
\hline $\begin{array}{l}\text { Miami-Dade, FL } \\
\text { (Nissen 1998) }\end{array}$ & $66 \%$ & 1,956 & $1.8 \%{ }^{\mathrm{a}, \mathrm{b}}$ & $\begin{array}{l}\text { Contract } \\
\text { Value }\end{array}$ \\
\hline $\begin{array}{l}\text { San Jose, CA } \\
\text { (Benner and Rosner 1998) }\end{array}$ & $117 \%$ & 1,561 & $3.0 \%{ }^{a, b}$ & $\begin{array}{c}\text { Firm } \\
\text { Revenue }\end{array}$ \\
\hline $\begin{array}{l}\text { San Francisco, CA } \\
\text { (Reich et al. 1999a) }\end{array}$ & $91 \%$ & 12,380 & $3.9 \%$ a,b & $\begin{array}{l}\text { Contract } \\
\text { Value }\end{array}$ \\
\hline $\begin{array}{l}\text { Detroit, MI } \\
\text { (Reynolds et al. 1999) }\end{array}$ & $62 \%$ & 2,300 & $2.5 \%{ }^{b}$ & $\begin{array}{c}\text { Contract } \\
\text { Value }\end{array}$ \\
\hline $\begin{array}{l}\text { San Francisco, CA } \\
\text { Airport and Port } \\
\text { (Reich et al. 1999b) }\end{array}$ & $91 \%$ & 14,190 & $\begin{array}{l}\text { 2.7\% (Airport) } \\
\text { 4.6\% (Port) }\end{array}$ & $\begin{array}{l}\text { Operating } \\
\text { Costs }\end{array}$ \\
\hline $\begin{array}{l}\text { New Orleans, LA } \\
\text { (Pollin et al. 2001) }\end{array}$ & $19 \%$ & 47,050 & $0.9 \%$ & $\begin{array}{l}\text { Operating } \\
\text { Costs }\end{array}$ \\
\hline $\begin{array}{l}\text { Oakland, CA } \\
\text { Airport and Port } \\
\text { (Zabin et al. 1999) }\end{array}$ & $44 \%$ & 3,111 & $\begin{array}{l}1.5 \% \text { (Airport) }^{2} \\
4.31 \% \text { (Port) }^{\mathrm{c}}\end{array}$ & $\begin{array}{c}\text { Firm } \\
\text { Revenue }\end{array}$ \\
\hline $\begin{array}{l}\text { Santa Monica, CA } \\
\text { (Pollin and Brenner 2000) }\end{array}$ & $87 \%$ & 2,078 & $\begin{array}{c}3.9 \% \text { (All) } \\
10.4 \% \text { (Hotel) } \\
9.6 \% \text { (Restaurant) }\end{array}$ & $\begin{array}{c}\text { Firm } \\
\text { Revenue }\end{array}$ \\
\hline $\begin{array}{l}\text { New York City, NY } \\
\text { (Sonn et al. 2002) }\end{array}$ & $57 \%$ & 62,000 & $0.3 \%^{\mathrm{b}, \mathrm{d}}$ & $\begin{array}{c}\text { Firm } \\
\text { Revenue }\end{array}$ \\
\hline
\end{tabular}
a. Proportions are for city service contracts only.
b. Calculations include direct costs only.
c, Figure is for the Real Estate Division at the Port of Oakland only.
d. Figure is for New York City subsidy recipients only. 
Table 3 Economic Impact of Various Living Wage Ordinances Retrospective Evidence

\begin{tabular}{|c|c|c|c|c|}
\hline $\begin{array}{l}\text { City } \\
\text { (Source) }\end{array}$ & $\begin{array}{c}\text { Fiscal Year } \\
\text { Living Wage } \\
\text { Implemented }\end{array}$ & $\begin{array}{l}\text { Wage Increase as a } \\
\text { Percentage of the } \\
\text { Minimum Wage }\end{array}$ & $\begin{array}{l}\text { Average Annual } \\
\text { Increase in Real } \\
\text { Contract Costs }{ }^{\text {a }} \\
\end{array}$ & $\begin{array}{l}\text { Number of } \\
\text { Contracts } \\
\text { Reviewed } \\
\end{array}$ \\
\hline $\begin{array}{l}\text { Baltimore, MD } \\
\text { (Weisbrot and } \\
\text { Sforza-Roderick 1996) }\end{array}$ & FY 96-97 & $44 \%$ & $-1.9 \%$ & 19 \\
\hline $\begin{array}{l}\text { Baltimore, MD } \\
\text { (Niedt et al. 1999) }\end{array}$ & FY 96-97 & $44 \%$ & $1.2 \%^{\mathrm{b}}$ & 26 \\
\hline $\begin{array}{l}\text { New Haven, CT } \\
\text { (Brenner and Luce 2003) }\end{array}$ & FY 97-98 & $56 \%$ & $-10.9 \%$ & 9 \\
\hline $\begin{array}{l}\text { Boston, MA } \\
\text { (Brenner and Luce 2003) }\end{array}$ & FY 99-00 & $57 \%$ & $-7.3 \%$ & 29 \\
\hline $\begin{array}{l}\text { Dane County, WI } \\
\text { (Elmore 2003) }\end{array}$ & FY 99-00 & $54 \%$ & $2.8 \%{ }^{b, c}$ & 12 \\
\hline $\begin{array}{l}\text { Corvallis, OR } \\
\text { (Brewer 2001) }\end{array}$ & FY 00-01 & $38 \%$ & $9.1 \%$ & 31 \\
\hline $\begin{array}{l}\text { San Francisco, CA } \\
\text { (Elmore 2003) }\end{array}$ & FY 00-01 & $\begin{array}{c}57 \% \text { (with health) } \\
78 \% \text { (without) }\end{array}$ & $1.0 \%{ }^{b, c}$ & - \\
\hline $\begin{array}{l}\text { Hartford } \\
\text { (Brenner and Luce 2003) }\end{array}$ & FY 00-01 & $\begin{array}{c}43 \% \text { (with health) } \\
71 \% \text { (without) }\end{array}$ & $33.4 \%$ & 2 \\
\hline
\end{tabular}
a. Percentages are weighted by contract value.
b. Contract cost increases are measured in nominal terms.
c. These figures are for the human services contracts covered by the living wage law in each locality.




\section{Notes}

${ }^{1}$ These figures do not include the nine cities where living wage laws have been passed and the subsequently repealed.

${ }^{2}$ It should also be noted that neither the Katz and Krueger (1992) analysis of the minimum wage effect on fast food employment in Texas, nor the similar analysis conducted by Spriggs (1993) in North Carolina and Missisippi, are from areas or periods where the minimum wage was relatively high.

${ }^{3}$ Although empirical assessments of efficiency wages are much rarer than theoretical treatments, there appears to be solid evidence of their existence (e.g. Cappelli and Chauvin 1991; Levine 1992; Campbell 1993). More importantly, there is a solid empirical connection between higher wages and lower indirect labor costs such as turnover and absenteeism whether due to efficiency wages or not (e.g. Freeman and Medoff 1984; Raff and Summers1987; Krueger and Summers 1987; Reich et al. 2003; Howes 2002).

${ }^{4}$ It is important to distinguish between monitoring or enforcing living wage laws and actually applying them to business assistance recipients. All business assistance cities were indeed enforcing their laws in the sense that they were monitoring economic development projects to see if any fell under the strictures of the living wage law. However, except for San Antonio, TX, Brenner et al. (2002) concluded that no business assistance cities had actually had a case where the law was applied to an actual business assistance recipient.

${ }^{5}$ Population figures are from 1999, drawn from the most recent Census Bureau estimates: http://eire.census.gov/popest/archives/place/SC100K-T1.txt. 
${ }^{6}$ In fact, the San Francisco ordinance, with a city-wide population of approximately 747,000 in 1999, actually covers a proportionally greater share of the city population than does New York, with a city-wide population of 7.4 million, 1.7 percent versus 0.8 percent respectively.

${ }^{7}$ It bears note that the Weisbrot and Sforza-Roderick study was attacked by the anti-minimum wage Employment Policies Institute shortly after its release for fabricating data and distorting results [Employment Policies Institute, 1998 \#78]. These charges, however, were without substance, as demonstrated by the Preamble Center staff [Preamble Center, 1999 \#77]. More importantly, as we discuss, the Weisbrot and Sforza-Roderick conclusions were supported by the subsequent analysis of Niedt et al.

${ }^{8}$ Unit-cost bids are typically submitted as an hourly rate for services performed, such as for security guard services or temporary office assistance. This form of bidding is most prevalent when cities are unsure of the exact level of services required in the future, and want to maintain the contractual flexibility to increase or decrease their usage as concrete needs are identified. ${ }^{9}$ It is also true that most firms highly impacted by geographically-based measures also have very localized product markets. This was the case for firms covered by living wage proposals in Santa Monica, CA, and New Orleans, LA (Pollin and Brenner 2000; Pollin et al. 2002).

${ }^{10}$ Pollin et al (2001) and Pollin and Brenner (2000) estimate that price increases, even on the order of 10 percent, are not an impractical response to living wage mandates, given the sharp price differences that already exist between the tourist and non-tourist segments of the hotel and restaurant market within Santa Monica and New Orleans. 